J. Lake Sci.(湖泊科学), 2020, 32(3): 665-675

DOI 10. 18307/2020. 0307

(C) 2020 by Journal of Lake Sciences

\title{
洪泽湖入湖河流沉积物有机磷分布特征及外源输入对其形态转化的 影响”
}

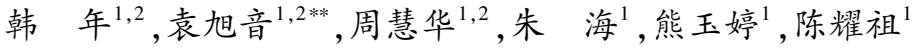 \\ (1: 河海大学环境学院, 南京 210098) \\ ( 2 : 浅水湖泊综合治理与资源开发教育部重点实验室,南京 210098)
}

\begin{abstract}
摘 要: 为探究洪泽湖人湖河流沉积物有机磷的空间分布及外源输人对其形态转化的影响, 本文利用 Ivanoff 法开展有机 磷形态特征研究, 并通过实验室添加常见外源有机质和铁离子, 深人探讨外源物质对沉积物有机磷形态变化的长期影响. 研究结果表明, 洪泽湖人湖河流沉积物有机磷含量范围为 $34.8 \sim 398.6 \mathrm{mg} / \mathrm{kg}$, 占总磷的 $7.7 \% \sim 36.9 \%$, 其中非活性有机磷 (NOP) > 中活性有机磷 (MLOP) > 活性有机磷 ( LOP). 濉河沉积物 LOP 平均占比为 $19.4 \%$, 高于其他河流, 而成子河 NOP 平均占比最高, 为 $56.41 \%$, 表明有机磷的空间分布不均匀. 总体而言, 安河和滩河沉积物中总氮、总磷和有机磷含量显著 高于成子河和淮河, 显示前两条河流有较高的污染水平. 冗余分析表明河流沉积物有机磷形态明显受到其理化性质影 响, 而不同污染程度沉积物的影响因素有所不同. 外源物质添加能够活化沉积物的有机磷, 促使 NOP 向 LOP 和 MLOP 转 化, 有机质输人引起的沉积物有机磷形态变化要大于铁元素输人, 而外源物质输人对污染较重河流沉积物的有机磷转化 作用更为显著. 因此,减少人湖河流周边的外源污染排放是减少湖泊生物可利用磷的有效途径.
\end{abstract}

关键词: 沉积物; 有机磷;空间分布;形态转化;洪泽湖

\section{Distribution characteristics of organic phosphorus in the sediments of rivers entering the Lake Hongze and the effects of exogenous substances on their fraction transformation *}

\author{
HAN Nian ${ }^{1,2}$, YUAN Xuyin ${ }^{1,2 * *}$, ZHOU Huihua ${ }^{1,2}$, ZHU Hai $^{1}$, XIONG Yuting $^{1}$ \& CHEN Yaozu ${ }^{1}$ \\ (1: College of Environment, Hohai University, Nanjing 210098, P.R.China) \\ (2: Key Laboratory of Integrated Regulation and Resource Development on Shallow Lakes, Ministry of Education, Nanjing \\ 210098, P.R.China)
}

\begin{abstract}
In order to explore the spatial distribution of organic phosphorus in the sediments of the rivers entering Lake Hongze and the effects of exogenous inputs on its fraction transformation, we used the Ivanoff method to study the fraction characteristics of organic phosphorus in these sediments. The long-term effects of exogenous substances on the fraction changes of organic phosphorus in sediments were also investigated by adding organic matter and iron ions in the laboratory. The results showed that the contents of organic phosphorus in the sediments of the rivers entering Lake Hongze ranged from $34.8 \mathrm{mg} / \mathrm{kg}$ to $398.6 \mathrm{mg} / \mathrm{kg}$, accounting for $7.7 \%$ to $36.9 \%$ of the total phosphorus, and which showed non-active organic phosphorus (NOP) > middle-active organic phosphorus (MLOP) > active organic phosphorus ( LOP). The average proportion of LOP in the sediments of Suihe River was $19.4 \%$, which was higher than that of other rivers. The average proportion of NOP in Chengzi River was 56.41\%, which indicated that the spatial distribution of organic phosphorus was uneven. Overall, the contents of total nitrogen, total phosphorus and organic phosphorus in sediments of Anhe and Suihe rivers were significantly higher than those of Chengzi and Huaihe rivers, indicating that the former two rivers had a higher pollution level. Redundancy analysis showed that the fractions of organic phosphorus in river sediments were affected by their physicochemical properties, indicating the different influencing factors for different pollution levels of sediment. The addition of exogenous substances can mineralize organic phosphorus in sediments and promote their transformation
\end{abstract}

* 2019-10-08 收稿; 2019-10-24 收修改稿.

国家自然科学基金项目 (41372354,41601540) 和江苏省自然科学基金项目 (BK20160859) 联合资助.

** 通信作者;E-mail:yxy_hjy@ hhu.edu.cn. 
from NOP to LOP and MLOP. The change range of organic phosphorus fraction caused by organic matter was greater than that caused by iron, and the transformation effect of exogenous substances on organic phosphorus in heavily polluted sediments was more significant. Therefore, it is an effective way to reduce the bioavailable phosphorus of Lake Hongze by reducing the discharge of exogenous pollutants around rivers.

Keywords: Sediment; organic phosphorus; spatial distribution; fraction transformation; Lake Hongze

有机磷是沉积物磷的重要组成部分, 具有潜在的释放风险并转变为其他生物可利用形式 ${ }^{[1-2]}$. 近年来, 关于沉积物中有机磷的含量、形态、生物有效性等方面已有一些研究 ${ }^{[3-4]}$, 这些研究结果表明, 沉积物有机磷 在水体磷循环中起着至关重要的作用 ${ }^{[5]}$. 沉积物中有机磷的含量约占总磷的 $20 \% \sim 80 \%{ }^{[6]}$, 其分布和转化不 仅与来源相关, 且与沉积物的理化性质有关 ${ }^{[7]}$. 以往有关沉积物有机磷研究大多限于单一河流或湖泊沉积 物, 少有结合不同地理环境、污染状况及土地利用方式的对比研究, 也缺少外源输人条件下沉积物有机磷形 态的长期变化分析, 而这些综合研究对于深人了解流域沉积物有机磷的空间变化特征、迁移与转化行为十 分重要.

洪泽湖水质状况受到人湖河流的显著影响 ${ }^{[8]}$, 而这些人湖河流附近人类活动频繁, 且有较多的有机污 染源 (如畜禽养殖、生活污水). 因此, 为了控制洪泽湖磷的输人, 分析研究人湖河流沉积物有机磷的空间分 布特征相当重要. 同时, 人湖河流周边存在较多的生活污水、工业废水等污染源, 进人水体的污染物质会影 响有机磷的转化, 增加水体富营养化风险. 研究外源物质对有机磷形态转化的长期影响可更加深人了解洪 泽湖流域有机磷的循环过程, 预测水体磷的长期变化趋势. 本研究采用 Ivanoff 等 $^{[9]}$ 的连续提取方法分析沉 积物有机磷形态组成, 利用穴余分析研究有机磷分布的影响因素; 设计室内连续培养试验, 探究外源添加物 对不同污染水平沉积物有机磷形态转化的长期效应, 以期为洪泽湖及周边流域开展有针对性的流域环境保 护与管理提供指导.

\section{1 材料与方法}

\section{1 研究区域概况}

洪泽湖位于江苏淮安市西南部, 湖泊面积 $1597 \mathrm{~km}^{2}$, 是我国第四大淡水湖. 现有研究资料表明, 洪泽湖 水体的主要污染物为总磷, 而人湖河流输人为磷的主要来源 ${ }^{[8]}$. 本研究以洪泽湖人湖河流成子河、安河、濉 河和淮河的沉积物为研究对象, 采样点分布如图 1 所示. 成子河沿途经过宿迁市、泗阳县等进人湖区, 土地 利用以草地、城镇用地为主, 也有少量的养殖区 ${ }^{[10]}$; 安河起源于房亭河的荆山引河口, 上游土地利用以林地、 耕地为主, 中游分布有较多的水产养殖地; 滩河自宿县的张树闸起, 穿浍塘沟闸分为两股, 一股沿故道东流, 为老濉河,一股东南流为新挖河道, 为新滩河, 本文研究的为老濉河. 近年来安河、濉河两岸污染负荷持续增 加, 主要是由于城市生活污水、工业废水和养殖废水的排人 ${ }^{[11]}$. 淮河 (江苏段) 为洪泽湖最大人湖河流, 其水 系多年平均径流量为 452.0 亿 $\mathrm{m}^{3}$, 人湖水量占总人湖径流量的 $70 \%$ 以上 ${ }^{[12]}$, 其采样区分布有大量耕地, 农业 面源污染是磷的主要污染来源.

\section{2 样品采集与处理}

结合河流分布特征、周边环境、土地利用方式, 于 2017 年 6 月, 采用抓斗式采样器自人湖河流东部到西 部 (上游至下游) 采集表层 $(0 \sim 10 \mathrm{~cm})$ 沉积物. 为防止样品采集的偶然性和随机性, 每个采样点均采集 3 个 平行样并现场混合后置于封口聚乙烯袋中, 带回实验室冷藏. 然后通过自然风干, 去除样品中的小石子、贝 壳和腐根等杂物, 研磨并过 100 目篮后装于封口聚乙烯袋中,保存在低温状态供分析.

\section{3 样品测定方法}

沉积物样品分析测定指标包括常量元素、 $\mathrm{pH}$ 、粒度、有机质 $(\mathrm{OM})$ 、总氮 $(\mathrm{TN})$ 、总磷 ( TP)、无机磷 (IP) 以 及不同形态有机磷 $(\mathrm{OP})$.

常量元素含量使用荷兰帕纳科公司的 PW2440 型射线荧光分析仪测定, $\mathrm{pH}$ 采用电极法测定, 粒度根据 国际上应用较广的伍登一温特华斯的粒度分级方案进行分析 ${ }^{[13]}, \mathrm{OM} 、 \mathrm{TP} 、 \mathrm{TN} 、 \mathrm{OP}$ 等指标采用常规化学分析 方法测定. OM 含量采用水合热重铬酸钾容量法测定, TP 含量采用硫酸一高氯酸消煮一钿锑抗比色法测定, 


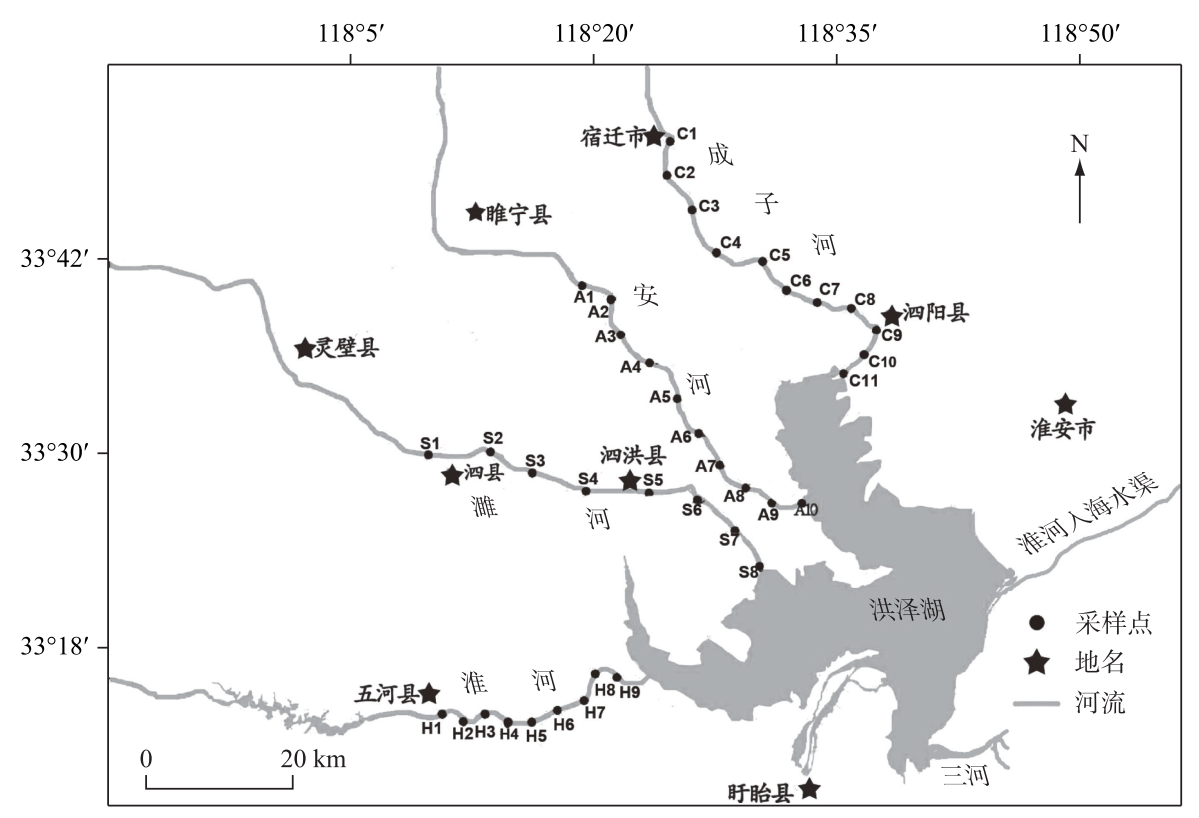

图 1 研究区域与采样点分布

Fig.1 Map of study areas showing sampling sites distribution

$\mathrm{TN}$ 含量采用凯氏消煮法测定, $\mathrm{OP}$ 含量采用灼烧法测定, IP 含量由 TP 与 OP 含量的差值算出 ${ }^{[14]}$. 沉积物有 机磷分级连续提取参照 Ivanoff 等提出的土壤 $\mathrm{OP}$ 分级的方法, 具体提取方法见表 1. 实验中对所有样品均取 3 份平行测定并取平均值, 数据误差 $<10 \%$.

表 1 沉积物有机磷分级提取流程

Tab.1 Extraction procedure of organic phosphorus fractions in sediments

\begin{tabular}{cl}
\hline 形态 & 提取方法 \\
\hline 活性有机磷 & 取 $1 \mathrm{~g}$ 沉积物加入 $50 \mathrm{~mL} 0.5 \mathrm{~mol} / \mathrm{L} \mathrm{NaHCO}_{3}(\mathrm{pH}=8.5)$, 振荡 $16 \mathrm{~h}, 8000 \mathrm{r} / \mathrm{min}$ 离心 $10 \mathrm{~min}$ 获提取 \\
& 液, 过滤后用钼蓝比色法测定无机磷与总磷, 差值为活性有机磷 $(\mathrm{LOP})$. \\
中活性有机磷 & $\mathrm{NaHCO}_{3}$ 提取后残渣中加人 $50 \mathrm{~mL} 1.0 \mathrm{~mol} / \mathrm{L} \mathrm{HCl}$, 振荡 $3 \mathrm{~h}, 8000 \mathrm{r} / \mathrm{min}$ 离心 $10 \mathrm{~min}$, 上清液无机磷 \\
& 与总磷的差值为盐酸提取有机磷; 在 $\mathrm{HCl}$ 提取后的残渣中加人 $50 \mathrm{~mL} 0.5 \mathrm{~mol} / \mathrm{L} \mathrm{NaOH}$ 振荡 $16 \mathrm{~h}$, \\
& $8000 \mathrm{r} / \mathrm{min}$ 离心 $10 \mathrm{~min}$ 获取提取液, 用浓 $\mathrm{HCl}$ 调节 $\mathrm{pH}$ 至 0.2 并离心, 上清液与沉淀中无机磷与 \\
& 总磷的差值分别为富里酸和腐殖酸结合态有机磷, 富里酸结合态有机磷与盐酸提取有机磷之和 \\
& 为中等活性有机磷 $(\mathrm{MLOP})$. \\
& 将 $\mathrm{NaOH}$ 溶液提取后的残渣于 $550^{\circ} \mathrm{C}$ 灼烧 $1 \mathrm{~h}$, 加人 $50 \mathrm{~mL} 1 \mathrm{~mol} / \mathrm{L} \mathrm{H}_{2} \mathrm{SO}_{4}$, 振荡 $24 \mathrm{~h}$ 后 $8000 \mathrm{r} / \mathrm{min}$ \\
& 离心 $10 \mathrm{~min}$, 上清液中总磷为残渣态有机磷. 残渣态有机磷与腐殖酸结合态有机磷之和为非活性 \\
& 有机磷 $(\mathrm{NOP})$.
\end{tabular}

\section{4 外源添加模拟实验}

生活污水和工业废水是洪泽湖人湖河流的主要污染来源, 因此, 添加有机质和铁离子来模拟这两种废 水. 本研究分别以腐植酸和氯化铁作为实验物质, 探究它们进人沉积物后对有机磷形态变化的长期影响, 本 实验主要模拟一个季节有机磷的变化 (夏季). 将采集的沉积物按河流污染水平进行均匀混合, 根据现场采 样可知, 安河和滩河周边污染显著重于成子河和淮河, 故将污染较重的安河、滩河沉积物和污染较轻的成子 河、淮河沉积物组成混合样, 实验中各取 $100 \mathrm{~g}$ 于培养血中, 分别用去离子水、 $10 \mathrm{~g} / \mathrm{L}$ 腐殖酸溶液及 $10 \mathrm{~g} / \mathrm{L}$ $\mathrm{FeCl}_{3}$ 溶液各 $10 \mathrm{~mL}$ 加人到土样中并震荡混合, 加人蒸馏水使沉积物含水呈饱和状态 (完全湿润但无水流 
出), 然后将沉积物样置于 $30 \pm 1^{\circ} \mathrm{C}$ 条件下恒温密闭培养, 每隔 3 天用注射器调节沉积物含水量使之保持饱和 状态. 实验共持续 90 天, 分别于第 $5 、 10 、 20 、 30 、 60$ 和 90 天进行取样并测定各形态有机磷含量.

\section{5 数据统计与分析方法}

利用 Excel 2010 软件对实验数据进行整理统计, 使用 Origin 9.0 软件进行参数空间和时空变化作图, 采 用 Canoco 5.0 软件分析沉积物的理化性质与有机磷形态的相关性.

\section{2 洪泽湖不同入湖河流沉积物的理化性质及磷的分布特征}

\section{1 沉积物的主要理化性质}

洪泽湖人湖河流沉积物的主要理化性质如表 2 所示. 总体看, 大部分沉积物的 $\mathrm{pH}$ 值大于 8 , 而淮河沉积 物 $\mathrm{pH}$ 略低, 平均值为 7.66 , 表明研究区沉积物偏碱性. 人湖河流沉积物中 $\mathrm{CaO}$ 含量明显高于太湖等人湖河 流 ${ }^{[15]}$, 这是造成沉积物偏碱性的原因. 安河、滩河沉积物中营养盐 (TN、TP) 的平均含量明显高于其他两条 河流, 综合有机质的分析, 显示其污染程度相对较高. 较高比例的黏粒容易吸附外来的营养物质 ${ }^{[16]}$, 这可能 是安河、濉河营养盐含量较高的原因之一.

表 2 不同人湖河流沉积物的主要理化性质

Tab.2 Major physicochemical properties of river sediments of different rivers entering the lake

\begin{tabular}{|c|c|c|c|c|c|c|c|c|}
\hline \multirow{2}{*}{ 指标 } & \multicolumn{2}{|c|}{ 成子河 } & \multicolumn{2}{|c|}{ 安河 } & \multicolumn{2}{|c|}{ 濉河 } & \multicolumn{2}{|c|}{ 淮河 } \\
\hline & 范围 & 平均值 & 范围 & 平均值 & 范围 & 平均值 & 范围 & 平均值 \\
\hline $\mathrm{pH}$ & $7.45 \sim 9.05$ & 8.14 & $7.97 \sim 8.66$ & 8.38 & $7.86 \sim 8.63$ & 8.33 & $7.36 \sim 8.25$ & 7.66 \\
\hline $\mathrm{OM} / \%$ & $1.02 \sim 2.37$ & 1.52 & $0.97 \sim 3.80$ & 1.85 & $1.13 \sim 2.31$ & 1.68 & $1.01 \sim 3.01$ & 1.76 \\
\hline $\mathrm{Al}_{2} \mathrm{O}_{3} / \%$ & $7.39 \sim 37.94$ & 19.14 & $7.53 \sim 12.07$ & 10.11 & $7.92 \sim 14.05$ & 10.21 & $13.71 \sim 27.46$ & 19.37 \\
\hline $\mathrm{CaO} / \%$ & $0.94 \sim 6.60$ & 4.55 & $3.71 \sim 6.62$ & 5.75 & $2.64 \sim 7.77$ & 5.03 & $4.66 \sim 7.44$ & 5.63 \\
\hline $\mathrm{MnO} / \%$ & $0.00 \sim 0.12$ & 0.03 & $0.02 \sim 0.17$ & 0.06 & $0.01 \sim 0.10$ & 0.06 & $0.04 \sim 0.12$ & 0.07 \\
\hline $\mathrm{Fe}_{2} \mathrm{O}_{3} / \%$ & $2.77 \sim 4.57$ & 3.84 & $1.76 \sim 3.73$ & 2.93 & $0.04 \sim 4.71$ & 1.99 & $3.38 \sim 4.61$ & 4.04 \\
\hline $\mathrm{TN} /(\mathrm{mg} / \mathrm{kg})$ & $687 \sim 930$ & 841 & $789 \sim 1310$ & 1114 & $924 \sim 1298$ & 1060 & $554 \sim 1020$ & 921 \\
\hline $\mathrm{TP} /(\mathrm{mg} / \mathrm{kg})$ & $474 \sim 672$ & 557 & $515 \sim 1079$ & 831 & $641 \sim 715$ & 696 & $449 \sim 682$ & 582 \\
\hline 黏粒/\% & $1.82 \sim 9.44$ & 4.26 & $3.11 \sim 17.76$ & 10.57 & $2.92 \sim 16.27$ & 9.89 & $1.82 \sim 9.44$ & 6.27 \\
\hline 粉砂粒/\% & $38.73 \sim 71.31$ & 41.24 & $43.21 \sim 77.28$ & 68.21 & $37.11 \sim 73.44$ & 60.52 & $38.73 \sim 71.31$ & 55.13 \\
\hline 粗砂粒/\% & $28.22 \sim 67.19$ & 54.50 & $16.88 \sim 32.91$ & 22.22 & $19.42 \sim 43.12$ & 29.59 & $18.22 \sim 57.19$ & 38.60 \\
\hline
\end{tabular}

\section{2 沉积物磷的空间变化特征}

人湖河流沉积物中 TP 的空间变化特征如图 2 所示. 从图 2 可知, 不同河流沉积物 TP 的空间变化存在 差异性. 就采样区上中下游来看, 成子河 TP 含量中游地区较低, 上下游略高, 这是因为上游采样区临近宿迁 市城区, 且有少量水产养殖; 中游沿河分布有大量水生植物, 对人湖氮、磷有一定的削减作用, 而下游又进人 泗阳城区, 污染源增多导致磷含量升高. 安河、濉河沉积物 TP 含量表现出下游>中游>上游, 这是因为这两条 河流上游区域草地、林地分布较为广泛, 而下游人口分布密集, 生活污水等外源输人较多, 且下游是洪泽湖 的中心区, 周围大型船舶来往频繁. 淮河沉积物上游 H1 点由于受五河县县城生活污染物的影响, 其 TP 含量 略高, 其他采样点 TP 含量相对较低, 因为中下游采样点附近没有大型城镇. 根据刘鸿亮等 ${ }^{[17]}$ 关于沉积物磷 的初步研究, 通常将沉积物分为严重污染 ( $T P \geqslant 1000 \mathrm{mg} / \mathrm{kg}$ )、中度污染 $(500 \mathrm{mg} / \mathrm{kg}<\mathrm{TP}<1000 \mathrm{mg} / \mathrm{kg}$ ) 和未 污染 ( $\mathrm{TP} \leqslant 500 \mathrm{mg} / \mathrm{kg}$ ), 基于这个标准, 洪泽湖人湖河流大部分处于中度污染, 其中安河和濉河沉积物污染 较重, 而成子河和淮河沉积物的污染较轻.

沉积物 $\mathrm{OP}$ 与 IP 含量组成如图 2 所示, 安河和滩河沉积物 OP 含量显著高于成子河和淮河, 是因为前者 沿河有较多的外源有机物输人. 此外, 周边环境也影响有机磷的分布, 如安河的 A7 采样点, 濉河的 S7 采样 点, $\mathrm{OP}$ 含量较同河流其他采样点低, 由于这些采样点处水生植物茂盛, 水生植物对磷的吸收导致 $\mathrm{OP}$ 含量较 低 ${ }^{[18]}$, 另外, 植物根系分泌的有机酸类物质改变周围沉积物的理化性质, 从而导致 OP 的转化与释放, 降低 沉积物中 $\mathrm{OP}$ 含量 ${ }^{[19]}$. 


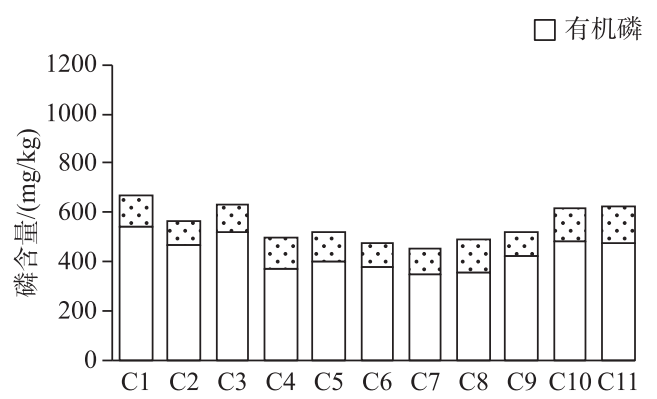

(a) 成子河采样点

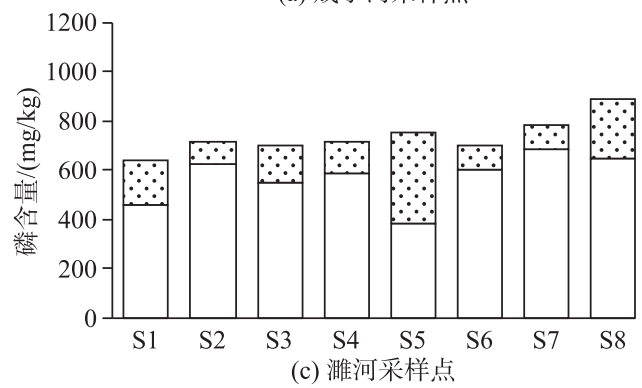

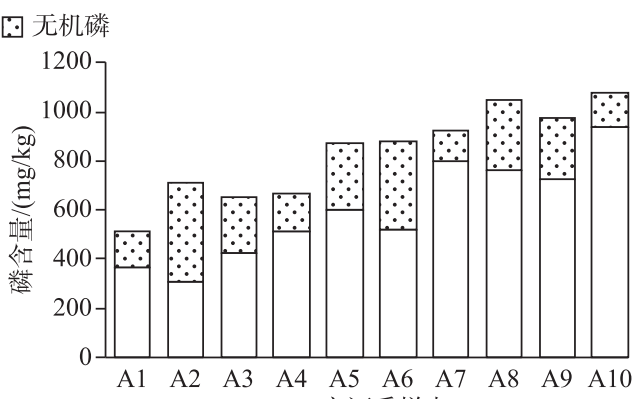

(b) 安河采样点

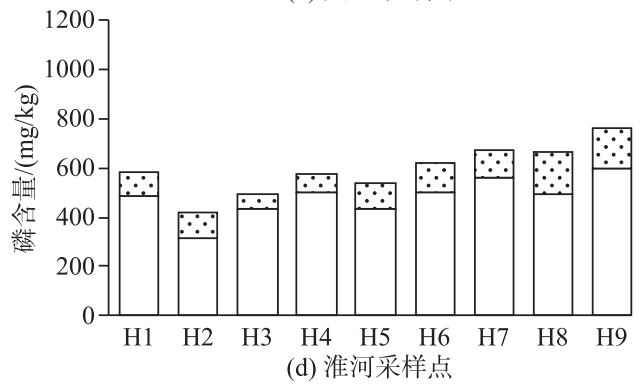

图 2 洪泽湖不同人湖河流沉积物中有机磷 (OP) 和无机磷 (IP) 含量的空间分布

Fig. 2 Spatial distributions of organic phosphorus and inorganic phosphorus contents in the sediments of different rivers entering Lake Hongze

\section{3 不同河流沉积物中有机磷形态的空间变化特征}

沉积物中不同形态有机磷含量的分布及变化如图 3 所示. 各河流沉积物有机磷含量范围为 $34.8 \sim 398.6$

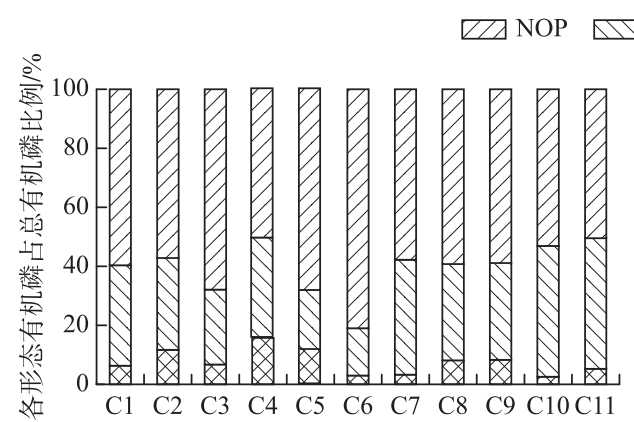

(a) 成子河采样点
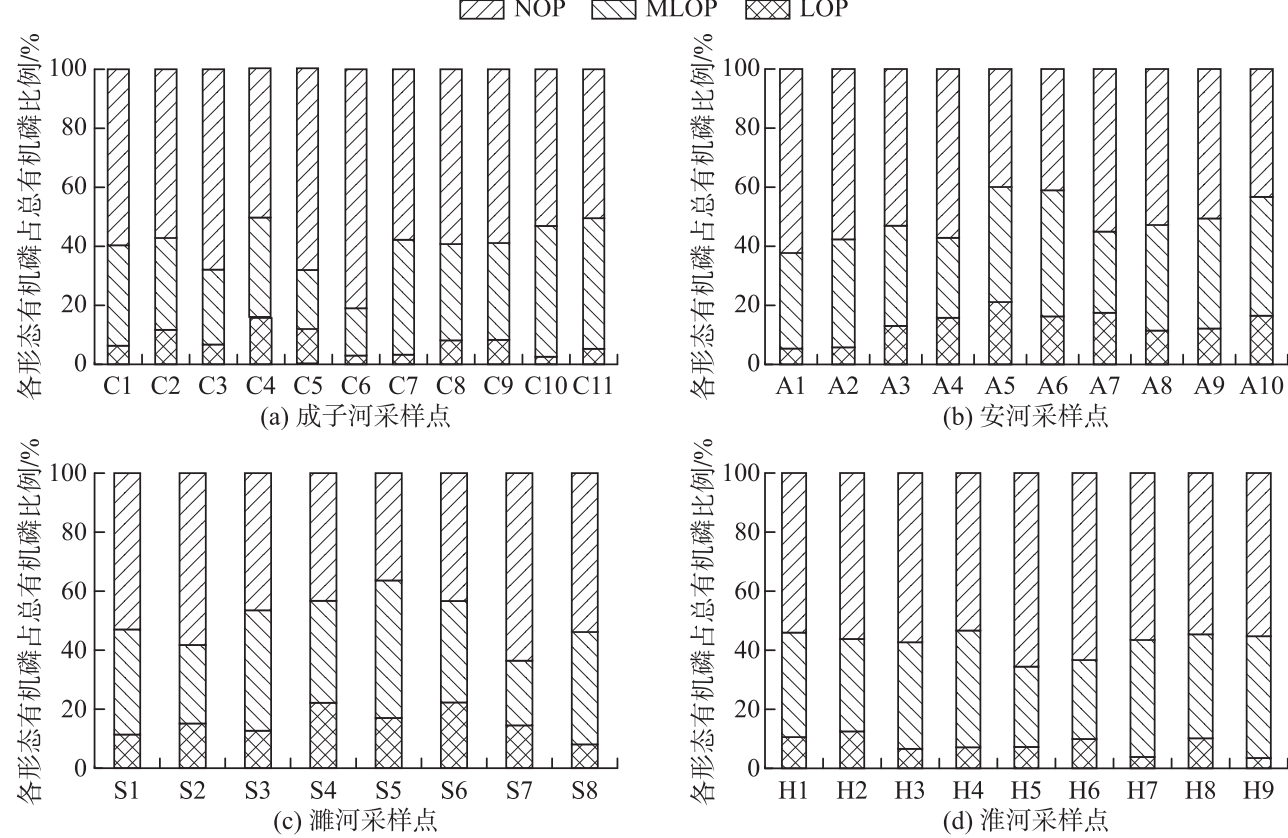

(b) 安河采样点

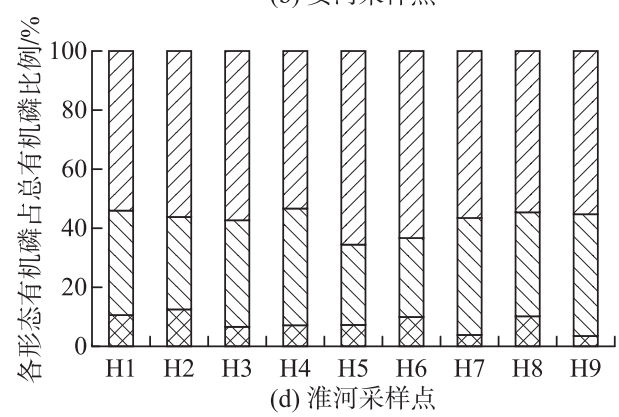

图 3 洪泽湖不同人湖河流沉积物中 3 种形态有机磷的空间分布

Fig.3 Spatial distribution characteristics of three organic phosphorus components in the sediments of different rivers entering Lake Hongze 
$\mathrm{mg} / \mathrm{kg}$, 占总磷的 $7.7 \% \sim 36.9 \%$. 不同河流沉积物有机磷形态占比顺序均为 NOP $>$ MLOP $>$ LOP. LOP 主要由核 酸、磷脂类等化合物组成, 与沉积物结合较为松散, 容易被分解为小分子化合物 ${ }^{[20-21]}$. 滩河沉积物 LOP 平均 占比为 $19.4 \%$, 高于其他河流, 淮河沉积物 LOP 占比最低, 这可能是因为淮河人湖水量大, 水体流速大, 使沉 积物中弱结合态的 LOP 容易释放至上覆水而被水生动植物吸收 ${ }^{[22]}$. 安河和濉河沉积物 LOP 占比高于其他 河流, 尤其是中游个别地点比较突出 (应该与养殖废水有关). MLOP 包括富里酸有机磷和腐殖酸有机磷, 多 为易分解的生物大分子, 稳定性差, 在一定条件下可水解或矿化为溶解性的小分子有机磷或溶解性磷酸根, 具有潜在的生物有效性 ${ }^{[23]}$. 安河和漼河沿岸人类活动频繁, 外源营养物质输人较多, MLOP 的比例相对较 高, 而沿河的变化不明显; 成子河周围多草地, 外源输人物相对较少, 故而 MLOP 占比较低, 但是从上游到下 游比例有所升高. NOP 的来源主要是生物残体分解, 是比较稳定的有机磷, 但可在有机质矿化过程中部分转 化为生物可利用磷 ${ }^{[24]}$. 成子河、安河、濉河和淮河沉积物有机磷占比均以 NOP 为主, 分别为 $56.41 \%$ 、 $46.33 \% 、 47.81 \%$ 和 $52.62 \%$, 表明不同河流沉积物有机磷总体构成一致,但是组成比例存在差别. 安河和滩河 沉积物 NOP 在上游占比较高, 这主要是由于上游采样点有较多的林地, 而下游有所下降; 由于下游有养殖、 生活污水的加人, 活性态有机磷的比例增加. 此外, 已有研究表明, 长期施肥的土壤, $\mathrm{OP}$ 较易从稳定形态向 活性形态转化 ${ }^{[25]}$. 另外, 安河和滩河沉积物 LOP 和 MLOP 占比显著高于成子河和淮河, 表明安河和濉河沉 积物有机磷存在较大的释放风险.

\section{3 沉积物有机磷形态分布的影响因素分析}

为分析沉积物基本理化性质对有机磷形态的影响, 采用㝋余分析 (RDA) 方法分析沉积物主要理化性质 与有机磷形态的关系 (图 4), 按河流的污染水平分为污染较重的河流 (安河和滩河) 沉积物及污染较轻的河 流 (成子河和淮河) 沉积物, 并分别进行讨论.

图 4 显示, 有机质与污染较重的沉积物中 LOP、MLOP、NOP 均呈显著的正相关关系 (箭头长, 夹角小), 说明有机质可能是有机磷的重要载体, 在某种程度上决定了有机磷的含量, 这与徐健等 ${ }^{[26]}$ 的研究结果相一 致. 将图 4a 和图 $4 \mathrm{~b}$ 的结果进行对比发现, 沉积物性质对污染较轻河流的沉积物影响稍弱 (箭头长度短), 原 因可能是污染较轻河流沉积物中有机磷组分变化较小, 导致与沉积物性质相关性不显著. 污染较重河流的 沉积物中, 黏粒与磷形态存在较强的正相关, 粉砂粒与污染较轻河流的沉积物呈正相关, 说明细颗粒能够吸 附更多有机磷 ${ }^{[27]}$. 化学成分对磷形态影响较大的是 $\mathrm{Al}_{2} \mathrm{O}_{3}$ 和 $\mathrm{Fe}_{2} \mathrm{O}_{3}$, 特别是与污染较重河流的沉积物中 LOP 及 MLOP 达到了显著的正相关, 因为污染重的河流沉积物中有机质含量较高, 铁、铝离子的电子转换促进了

(a) 污染较重的河流

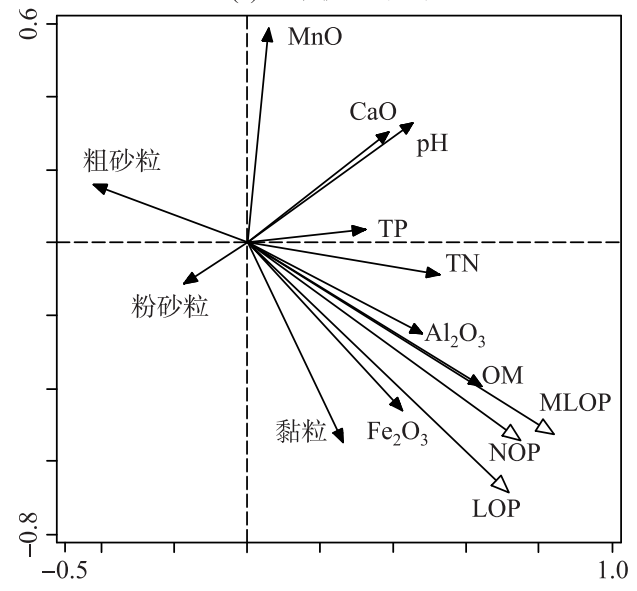

(b) 污染较轻的河流

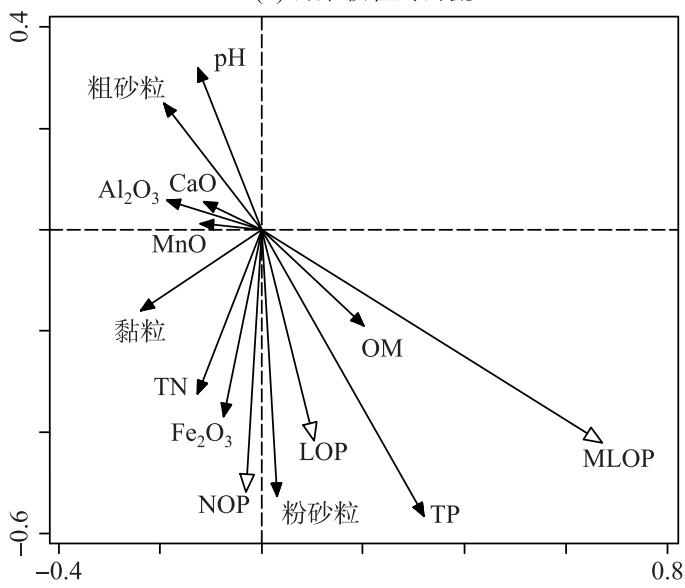

图 4 洪泽湖人湖河流沉积物中有机磷形态与理化性质的圥余分析

Fig.4 Redundancy analysis of organic phosphorus fractions and physicochemical properties of the sediments of different rivers entering Lake Hongze 
有机质的矿化, 使 NOP 向 LOP 及 MLOP 转化 ${ }^{[28]} \cdot \mathrm{pH}$ 与成子河和淮河沉积物中磷形态存在较强的负相关, 说明碱性条件有利于有机磷的释放 ${ }^{[29]}$. 沉积物中 TN 和 TP 与有机磷形态都有一定的正相关性, 尤其是安河 和濉河, 表明营养元素的输人会导致沉积物中不同形态有机磷含量升高.

总体而言, 沉积物理化性质对不同污染水平河流沉积物中有机磷形态的影响程度存在差异性, 反映了 洪泽湖人湖河流的地质背景、污染来源存在一定差异. 理化性质对污染较重的河流沉积物中有机磷的影响 更显著, 并且有机质及粒度对有机磷的影响比较显著. 沉积物 $\mathrm{pH}$ 、化学成分对有机磷形态均存在影响, 表明 沉积物有机磷组成受到内因和外因的共同影响.

\section{4 外源物质对不同污染水平沉积物有机磷组分转化的影响}

\section{1 有机质添加对沉积物有机磷组分的转化影响}

有机质对沉积物有机磷组分转化的影响如图 5 所示. 培养初期, 对照组 LOP 含量随时间先降低后缓慢 升高, 污染较轻的河流沉积物培养至第 60 天后 LOP 含量趋于稳定; 有机质的添加使污染较重和污染较轻的 河流沉积物中 LOP 含量最终分别增加了 2.2 和 1.7 倍. 污染较重的河流沉积物中 MLOP 含量随时间先缓慢 减少后增加, 变化趋势不明显; 添加有机质使 MLOP 含量快速降低, 培养至第 30 天升高, 而 NOP 含量变化趋 势相反, 表明 NOP 已转化为可利用形态. 相比而言, 对照组污染较轻的河流沉积物中 MLOP 含量随时间持 续缓慢降低, 添加有机质使得 MLOP 含量随时间反向升高, 从图 5 中可以看出添加有机质还使得 MLOP 含 量始终高于对照组. 由此可见, 随着培养时间的延长, 有机质的添加使 LOP、MLOP 含量增加, NOP 含量降 低,外源有机质能够促进沉积物 OP 由非活性态逐步向活性态转化.

有机质的添加能够加速有机磷的转化主要在于其为微生物的生长提供了丰富的碳源和矿物质, 从而提 高了微生物、磷酸酶等的活性, 加速了有机磷的转化 ${ }^{[30]}$; 另外, 实验以腐殖酸代替有机质, 腐殖酸能够络合、 螯合、吸附营养元素, 阻止溶液中磷素沉淀等作用, 从而间接活化沉积物中的有机磷 ${ }^{[31]}$, 这也是污染较轻的 河流沉积物中添加有机质后 MLOP 含量缓慢增加的原因. 如图 5 所示, 污染较重的河流沉积物中有机磷含 量变化幅度比污染较轻的河流沉积物大, 特别是培养的中后期, NOP 含量的下降幅度超过污染较轻河流的 两倍, 这是因为污染较重的安河和濉河沉积物 $\mathrm{pH}$ 偏碱性 $(\mathrm{pH}>8.5)$, 碱性条件下羟基将和磷酸盐竞争有机 键或者金属一有机键的结合点加快有机磷的转化 ${ }^{[32]}$. 另外, 通过抑制酸性, 也可以增加沉积物中微生物的活 动, 进而加速有机磷的转化进程 ${ }^{[33]}$. 而污染较轻的河流沉积物中有机质、氮磷营养盐含量相对较低, 有机质 等很快被分解消耗, 与污染较重河流的沉积物相比有机磷转化先达到平衡 ${ }^{[34]}$. 添加有机质还使得培养初期 各形态有机磷含量普遍高于对照组, 这主要是外源有机质增加了有机磷的基础含量.

\section{2 铁离子添加对沉积物有机磷组分转化的影响}

外源铁离子对沉积物有机磷组分转化的影响如图 5 所示. 培养前期 $(0 \sim 20 \mathrm{~d})$, 处理组相较于对照组各 形态有机磷含量均无明显变化. 从培养的第 30 天开始,两组沉积物中 LOP 含量均显著上升, 第 60 天增加量 最大, 污染较重的河流沉积物中 LOP 含量相比对照增加了 $22.12 \mathrm{mg} / \mathrm{kg}$, 是污染较轻的 2.2 倍; 添加铁离子还 使得污染较重的河流沉积物中 MLOP 含量随培养时间显著升高 $(P<0.05)$, 相对应的 NOP 含量降低, 表明这 部分有机磷有所转化. 而污染较轻的沉积物中 MLOP、NOP 均无明显的转化趋势. 这说明外源添加铁离子短 期内对 OP 转化具有一定的抑制作用, 其转化作用相对较弱; 而在污染较重的沉积物中, 随着培养时间的延 长, 铁离子对 $\mathrm{OP}$ 的转化逐步加强, 大大加快了 NOP 向 LOP、MLOP 的转化, 到培养的后期大致趋于平衡.

铁离子的添加同样对 $\mathrm{OP}$ 的转化产生影响, 但不同于有机质. 由图 5 可以看出, 在添加铁离子后培养前 20 天内各形态 $\mathrm{OP}$ 含量均无明显变化, 产生这种现象的原因在于加人的铁离子发生水解、结晶等反应生成 铁氧化物, 氢氧化物会覆盖在有机质表面, 从而抑制 $\mathrm{OP}$ 的转化 ${ }^{[35]}$; 另外, 外源铁离子为磷酸盐吸附提供了 大量的金属一有机键的结合位点, 这个过程将提高沉积物对 $\mathrm{OP}$ 的保持力 ${ }^{[36]}$. 故在模拟实验的中后期, 污染 较轻的沉积物本身富含较高的铁氧化物, 其各形态有机磷含量变化依然相对平缓; 而污染较重的河流沉积 物中 NOP 含量大幅度下降, MLOP 及 LOP 含量上升, 这主要是因为重污染沉积物中有机质含量较高, 加人 铁离子后, 能使以沉积物有机质作为其碳源的异养微生物铁还原菌大量繁殖, 异化铁还原加速了有机质的 分解, 从而加快了有机磷的转化进程 ${ }^{[37-38]}$; 此外, 污染较重的河流沉积物中较高含量的秥粒和有机质, 它们 


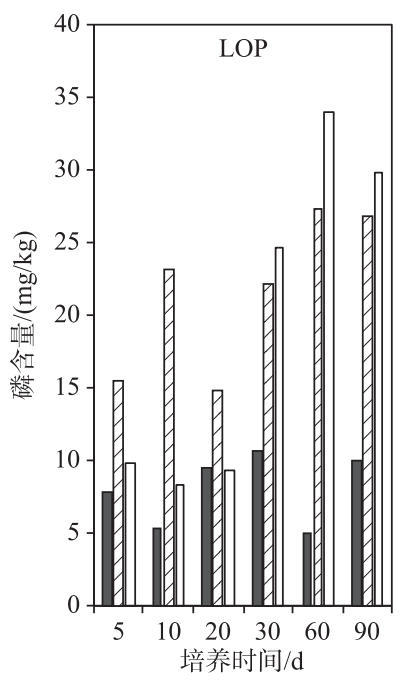

口对照 $\square$ 外源有机质 $\square$ 外源铁离子
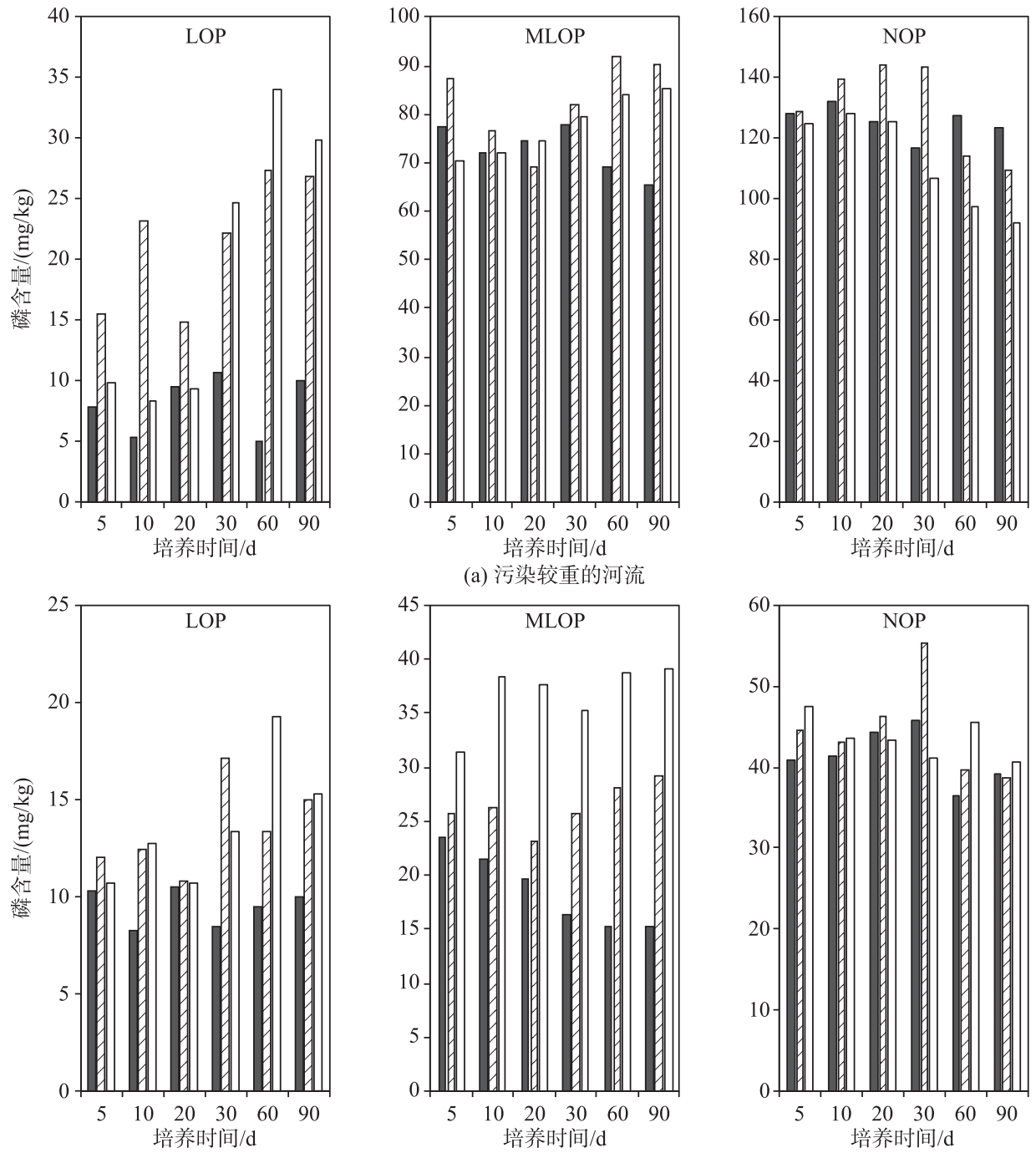

(b) 污染较轻的河流

图 5 外源添加对洪泽湖人湖河流沉积物中有机磷形态转化的影响

Fig. 5 Effects of exogenous addition on the transformation of organic phosphorus fractions in the sediments of rivers entering Lake Hongze

为微生物繁殖提供了良好的生长环境 ${ }^{[39]}$, 进一步促进了有机磷的矿化. 可见, 相较于生活污水, 工业废水的 长期作用对 OP 具有较强的潜在释放风险.

\section{5 结论}

1) 洪泽湖人湖河流沉积物偏弱碱性. 安河和濉河沉积物中 $\mathrm{Fe}_{2} \mathrm{O}_{3}$ 含量较高; 淮河沉积物中 $\mathrm{CaO}$ 和 $\mathrm{MnO}$ 含量较高. 安河和滩河沉积物的黏土含量高, 营养盐含量明显高于成子河和淮河沉积物, 说明河流沉积物污 染水平不仅与污染源输人有关, 还与沉积物的性质有关联.

2) 洪泽湖人湖河流沉积物中有机磷形态的组成存在差异, 总体上成子河和淮河沉积物非活性有机磷含 量占比相对较高, 而安河和濉河沉积物中活性有机磷、中等活性有机磷含量占比显著高于成子河和淮河, 表 
明安河和濉河沉积物中有机磷存在较大的释放风险.

3 ) 沉积物理化性质影响不同形态有机磷的含量及分布,其中沉积物营养元素与粒度组成的影响最为明 显. 除此之外, 铁、铝氧化物对污染较重的沉积物有机磷分布有明显的影响, 而对污染程度较轻的沉积物的 影响则较弱,表明研究区沉积物理化性质对污染程度不同的沉积物有机磷分布的影响存在差异.

4) 外源添加通常促进沉积物有机磷由非活性态向活性态转变,这种转变在污染较重的河流沉积物中转 变更加明显. 相较于富含有机质的生活污水, 含有金属离子工业废水的长期作用有利于有机磷释放, 具有较 强的潜在风险. 因此,控制沿河污染物排放是减少沉积物中磷释放风险的有效途径.

致谢: 感谢本团队研究人员万杰、周睿、张晓辉、章海燕在本研究采样过程的协助, 感谢张梦琪、唐黎在本研 究实验过程中的帮助.

\section{6 参考文献}

[ 1 ] Wang T, Wang K, Jiang X. Influence of rewetting process on distribution and release of phosphorus in sediments of East Lake Dongting. J Lake Sci, 2018, 30(4) : 937-947. DOI: 10.18307/2018.0407. [王婷, 王坤, 姜霞. 东洞庭湖沉积物 覆水后磷形态变化及其释放量. 湖泊科学, 2018, 30(4): 937-947.]

[ 2 ] Yang G, Qin YW, Han CN et al. Distribution of phosphorus fractions in surface sediments of Minjiang Mainstreams. Environmental Science, 2018, 39(5):2165-2173. [杨耿, 秦延文, 韩超南等. 岷江干流表层沉积物中磷形态空间分布特 征. 环境科学, $2018,39(5): 2165-2173$. ]

[ 3 ] Chang WL, He J, Wang B. Spatial and historical distribution of organic phosphorus driven by environment conditions in lake sediments. Journal of Environmental Sciences, 2018, 64(2) : 32-41.

[ 4 ] Xiong Q, Jiao LX, Wang SR et al. Characteristics and bioavailability of organic phosphorus from different sources of sediments in Dianchi Lake. Environmental Science, 2014, (11):4118-4126. [ 熊强, 焦立新, 王圣瑞等. 滇池沉积物有机 磷垂直分布特征及其生物有效性. 环境科学, 2014, (11) : 4118-4126. ]

[ 5 ] Wu FC, Jin XC, Zhang RY et al. Effects and significance of organic nitrogen and phosphorus in the lake aquatic Environment. J Lake Sci, 2010, 22(1) : 1-7. DOI: 10.18307/2010.0101. [ 吴丰昌, 金相灿, 张润宇等. 论有机氮磷在湖泊水 环境中的作用和重要性. 湖泊科学, 2010, 22(1): 1-7.]

[ 6 ] Dong DP, Zhang TX, Zhang TY et al. Characteristics of organic phosphorus fractions in the sediments of the black water aggregation in Lake Taihu. Environmental Science, 2016, 37(11): 4194-4202. [董丹萍, 章婷䂀, 张丁予等. 太湖湖泛 易发区沉积物中有机磷形态分布特征. 环境科学, 2016, 37( 11) : 4194-4202.]

[ 7 ] Lv C, He J, Zhou B et al. Distribution characteristics of organic phosphorus in sediments from Lake Hulun, China. Environmental Science Processes \& Impacts, 2015, 17(10): 1851-1858.

[ 8 ] Gao JF, Jiang ZG, Dou HS et al eds. Protection and development of the Great Freshwater Lakes in China. Beijing: Science Press, 2012. [高俊峰, 蒋志刚, 窦鸿身等. 中国五大淡水湖保护与发展. 北京: 科学出版社, 2012.]

[ 9 ] Ivanoff DB, Reddy KR, Robinson S. Chemical fractionation of organic phosphorus in selected histosols. Soil Science, $1998, \mathbf{1 6 3}(1): 36-45$.

[10] Li W, Du X, Lin ML et al. Spatial variation characteristics of water quality in Hongze Lake based on PCA and SOM. Resources and Environment in the Yangtze Basin, 2013, 22(12): 1593-1601. [李为, 都雪, 林明利等. 基于 PCA 和 SOM 网络的洪泽湖水质时空变化特征分析. 长江流域资源与环境, 2013, 22(12)：1593-1601.]

[11] Yuan Z, Xi LY, Wu Y. Investigation and research on the current situation of ecological environment in Hongze Lake basin. Geomatics World, 2017, (S1) : 78-81. [袁哲, 奚璐翊, 吴燕. 洪泽湖流域生态环境现状调查与研究. 给水排水, $2017,(\mathrm{~S} 1): 78-81$.

[12] Yu H, Zhang WB, Lu SY et al. Spatial distribution characteristics of surface sediments nutrients in lake Hongze and their pollution status evaluation. Environmental Sciences, 2010, 31(4): 961-968. [余辉, 张文斌, 卢少勇等. 洪泽湖表层底 质营养盐的形态分布特征与评价. 环境科学, 2010, 31(4) : 961-968.]

[13] Hou J, Wang C, Wang PF et al. Temporal variability and spatial distribution of granulometric composition of surface sediments and classification in Taihu Lake. Journal of Hohai University: Natural Sciences, 2013, 41(2) : 114-119. [侯俊, 王 超, 王沛芳等. 太湖表层沉积物粒度组成时空分布特征及分类命名. 河海大学学报: 自然科学版, 2013, 41(2): 114-119.] 
[14] Lu RS ed. Analytical method of soil agricultural chemistry. Beijing: China Agricultural Science and Technology Publishing House, 2000: 22-28. [鲁如坤. 土壤农业化学分析方法. 北京: 中国农业科技出版社, 2000: 22-28.]

[15] Zhou R, Yuan XY, Marip et al. Spatial distributions of transferable nitrogen forms and influencing factors in sediments from inflow rivers in different lake basins. Environmental Sciences, 2018, 39(3) : 1122-1128. [周睿, 袁旭音, Marip 等. 不同湖泊人湖河流沉积物可转化态氮的空间分布及其影响因素. 环境科学, 2018, 39(3): 1122-1128.]

[16] Liang HQ, Wang SR, Jin XC et al. Study on the organic phosphorus form \& distribution of different particle size fractions in the different polluted sediments. Chinese Agricultural Science Bulletin, 2007, 23(3):380-385. [梁海清, 王圣瑞, 金 相灿等. 不同污染程度沉积物不同粒级有机磷形态及其分布. 中国农学通报, 2007, 23(3): 380-385.]

[17] Liu HL, Jin XC, Jing YF. Engineering technology of environmental dredging of lake sediment. Engineering Science, 1999, 1 (1) : 81-84. [刘鸿亮, 金相灿, 荆一风. 湖泊底泥环境疏浚工程技术. 中国工程科学, 1999, 1(1): 81-84.]

[18] Zhou XN, Wang SR, Jin XC. Influences of submerged vegetation Hydrilla verticillata on the forms of inorganic and organic phosphorus and potentially exchangeable phosphate in sediments. Environmental Science, 2006, 27( 12) : 2421-2425. [ 周 小宁, 王圣瑞, 金相灿. 沉水植物黑藻对沉积物有机、无机磷形态及潜在可交换性磷的影响. 环境科学, 2006, 27 (12) : 2421-2425.]

[19] Sand-Jlnsen K, Jeppesen E, Nielsen K et al. Growth of macrophytes and ecosystem consequences in a lowland Danish stream. Freshwater Biology, 1989, 22(1): 15-32.

[20] Zhang R, Wu F, Liu C et al. Characteristics of organic phosphorus fractions in different trophic sediments of lakes from the middle and lower reaches of Yangtze River region and Southwestern Plateau, China. Environmental Pollution, 2008,152 (2) : 365-372.

[21] Mcdowell RW, Hill SJ. Speciation and distribution of organic phosphorus in river sediments: A national survey. Journal of Soils \& Sediments, 2015, 15(12): 2369-2379.

[22] Fang TH. Partitioning and behaviour of different forms of phosphorus in the Tanshui estuary and one of its tributaries, Northern Taiwan. Estuarine Coastal and Shelf Science, 2000, 50(5) : 689-701.

[23] Norton SA, Coolidge K, Amirbahman A et al. Speciation of Al, Fe, and P in recent sediment from three lakes in Maine, USA. Science of the Total Environment, 2008, 404(2/3): 276-283.

[24] Zhang W, Zhu X, Jin X et al. Evidence for organic phosphorus activation and transformation at the sediment-water interface during plant debris decomposition. Science of the Total Environment, 2017, 583: 458-465.

[25] Liu JL, Zhang FS, Yang FH. Study on soil phosphorus status of cultivated land and vegetable protected land in North China. Journal of Plant Nutrition and Fertilizers, 2000, 6(2): 179-186. [刘建玲, 张福锁, 杨奋翮. 北方耕地和蔬菜保护 地土壤磷素状况研究. 植物营养与肥料学报, 2000, 6(2): 179-186.]

[26] Xu J, Yuan XY, Ye HM et al. Spatial distribution of organic phosphorus in sediment and its environmental implication in the upper stream of Minjiang River. Environmental Science, 2019, 40(5):2186-2193. [徐健, 袁旭音, 叶宏萌等. 闽江 上游溪流沉积物有机磷空间分布及其环境意义分析. 环境科学, 2019, 40(5): 2186-2193.]

[27] Li QQ, Huo SL, Zan FY et al. The distribution of nutrients and particle size, their correlations in surface sediments of different lakes, China. Journal of Agro-Environment Science, 2010, 29(12) : 2390-2397. [李青芹, 霍守亮, 备逢宇等. 我 国湖泊沉积物营养盐和粒度分布及其关系研究. 农业环境科学学报, 2010, 29(12): 2390-2397.]

[28 ] Zhang W, Shan B, Zhang H et al. Assessment of preparation methods for organic phosphorus analysis in phosphorus-polluted Fe/Al-rich Haihe river sediments using solution 31P-NMR. PLoS ONE, 2013, 8(10) : e76525.

[29] Wang ZW. Characteristic research on the organic phosphorus in Erhai sediment [Dissertation]. Harbin: Northeast Agricultural University, 2012. [王忠威. 洱海沉积物有机磷及钲磷特征研究 [ 学位论文]. 哈尔滨: 东北农业大学, 2012.]

[30] Li YJ, Xiong SG, Wei ZM et al. Characteristics of organic phosphorus mineralized in Jingpo Lake sediments. Journal of Northeast Agricultural University, 2011, 42(8) : 112-116.

[31] Li CY, Dang TH, Wang WZ et al. Influence of humic acid on the adsorption behavior of phosphorus in agricultural soil. Journal of Soil and Water Conservation, 2011, 25(3): 77-82. [李春越, 党廷辉, 王万忠等. 腐殖酸对农田土壤磷素 吸附行为的影响研究. 水土保持学报, 2011, 25(3): 77-82.]

[32] Li N, Shan BQ, Zhang H et al. Organic phosphorus mineralization in the sediments under the impact of $\mathrm{pH}$ and temperature. Environmental Science, 2011, 32(4): 1008-1014. [李楠, 单保庆, 张洪等. 沉积物中有机磷在 $\mathrm{pH}$ 和温度影响 下的矿化机制. 环境科学, 2011, 32(4): 1008-1014.] 
[33] Pant HK, Reddy KR, Dierberg FE. Bioavailability of organic phosphorus in a submerged aquatic vegetation-dominated treatment wetland. Journal of Environmental Quality, 2002, 31(5) : 1748-1756.

[34] Yan XC, Wang MY, Xu XG et al. Migration of carbon, nitrogen and phosphorus during organic matter mineralization in eutrophic lake sediments. J Lake Sci, 2018, 30(2): 306-313. DOI: 10.18307/2018.0203. [间兴成, 王明玥, 许晓光 等. 富营养化湖泊沉积物有机质矿化过程中碳、氮、磷的迁移特征. 湖泊科学, 2018, 30(2) : 306-313.]

[35] Francko, David A. Epilimnetic phosphorus cycling: influence of humic materials and iron on coexisting major mechanisms. Canadian Journal of Fisheries and Aquatic Sciences, 1986, 43(2): 302-310.

[36] Yan DH. The characteristics and impact factors of organic phosphorus adsorption on iron oxides[Dissertation]. Hohhot: Inner Mongolia University, 2016. [颜道浩. 铁氧化物对有机磷的吸附特征及影响因素研究 [学位论文]. 呼和浩特: 内 蒙古大学, 2016.]

[37] Banwart SA. Reduction of iron( III ) minerals by natural organic matter in groundwater. Geochimica et Cosmochimica Acta, 1999, 63(19/20) : 2919-2928.

[38 ] Lonergan DJ, Jenter HL, Coates JD et al. Phylogenetic analysis of dissimilatory Fe( III )-reducing bacteria. Journal of Bacteriology, 1996, 178(8) : 2402-2408.

[39] Liu PY, Chen QC, Hu XK. Structure characteristics of core bacterial communities in surface sediments and analysis on their responses to environmental factors in the inlet of Bohai Bay. Microbiology China, 2018, 45(9): 106-121. [刘鹏远, 陈庆彩, 胡晓珂. 渤海湾湾口表层沉积物中的核心细菌群落结构及其对环境因子的响应. 微生物学通报, 2018, 45(9): 106-121.] 